Jurnal Sewaka Bhakti

Lembaga Penelitian dan Pengabdian Kepada Masyarakat

Universitas Hindu Indonesia Denpasar

Volume 4, Nomor 1 April 2020

ISSN: 2654-2935 (Online)

https://ejournal.unhi.ac.id/index.php/sewakabhakti

pp. 01-20

\title{
STRATEGI PENGEMBANGAN PARIWISATA MELALUI TRADISI BUDAYA TERHADAP PEREKONOMIAN MASYARAKAT DESA ADAT ASAK KARANGASEM
}

\author{
Ni Wayan Ari Sudiartini SE., M.Si ${ }^{1)}$, Putu Ari Mulyani, SE.,M.Si ${ }^{2)}$ \\ dan Yenni Rahman D ${ }^{3)}$ \\ Program Studi Manajemen, Fakultas Ekonomi, Universitas Mahendradatta \\ Jl. Ken Arok No 12, Peguyangan Denpasar Utara, Bali 80115 \\ Email : arie.lppm@gmail.com, santikadnipt@gmail.com
}

\begin{abstract}
The purpose of this study is to understand the tourism development strategies in the Indigenous Village of Asak Karangasem, which analyzes the impact of tourism development through cultural traditions on the economy of the community and describes the tourism development strategies that will be carried out and can find out aspects that need to be considered in tourism development so that it can affect the economy of the village community. This study uses the SWOT analysis method where by using this analysis we can find out the strengths, weaknesses, opportunities and threats that exist around the Asak Karangasem Indigenous Village. From the results of this study it can be proven that the tourism development strategy is able to have an impact on the economy of the surrounding community.
\end{abstract}

Key word. Strategy, Development, Tourism

\section{Pendahuluan}

Di Bali, pariwisata merupakan salah satu sektor unggulan yang telah tumbuh dan berkembang sedemikian rupa memberikan sumbangan penuh terhadap pembangunan daerah dan masyarakat Bali baik secara langsung maupun tidak langsung. Berbagai upaya telah dilakukan oleh pemerintah Kabupaten/Kota untuk mengembangkan potensi-potensi lokal sehingga wisatawan domestik maupun mancanegara tetap tertarik mengunjungi pulau Bali ini. Pariwisata yang dikembangkan di Bali adalah pariwisata Budaya. Hal ini merupakan salah satu keunikan yang dimiliki selain keindahan destinasi-destinasi yang ada di Bali.

Penetapan pengembangan pariwisata budaya sesuai dengan Peraturan Daerah Provinsi Bali Nomor 2 Tahun 2012 tentang kepariwisataan Budaya Bali. Peraturan ini menggantikan Peraturan Daerah Provinsi Daerah Tingkat I Bali Nomor 3 Tahun 1991 tentang 
Pariwisata Budaya yang dianggap sudah tidak sesuai lagi dengan kebijakan kepariwisataan nasional sebagaimana diatur dalam Undang-Undang Nomor 10 Tahun 2009 tentang Kepariwisataan. Namun demikian, pada kenyataannya kebijakan pengembangan pariwisata semata-mata dilakukan dengan pendekatan ekonomi dan mengabaikan kelestarian lingkungan serta kepentinga masyarakat lokal.

Dengan kondisi ini, tentu pariwisata dituntut untuk dapat memberikan interaksi yang lebih positif dan juga memberikan kontribusi pada pelestarian lingkungan alam dan budaya. Pengembangan wisata Budaya merupakan salah satu bentuk konkret dari pelestarian budaya dan manfaat bagi pengembangan kepariwisataan baik yang memiliki nilai-nilai pelestarian asset budaya, agar asset budaya tersebut dapat berfungsi lebih optimal untuk peningkatan dan pemahaman masyarakat akan pentingnya karya-karya budaya Bangsa sehingga mampu bersinergi dan berkoordinasi. Kegiatan yang perlu diperhatikan yaitu interprestasi, revitalisasi, reposisi, dan reaktualisasi asset budaya melalui strategi pengembangan dan pengelolaan yang sistematik melalui penataan wisata yang baik.

Desa Adat Asak Karangasem merupakan desa kuno di Bali yang dikenal dengan budaya unik. Dengan memiliki budaya yang unik maka desa ini dikenal melalui tradisi budayanya. Banyak wisatawan mancanegara yang datang dan mengenal Desa ini sebelum eksistensi daerah lain yang ada di Bali. Desa Adat Asak merupakan Desa pemekaran dari Desa Asak dengan pusat pemerintahan di Dusun Pertima Kecamatan Karangasem. Sebagai sebuah sosok desa kuno tentu syarat akan ritual agama dan tradisi budayanya yang unik. Dengan memiliki budaya yang unik maka desa ini perlu mengembangan beberapa strategi untuk dapat memperkenalkan secara luas dan mempertahankan eksistensi kearifan lokal yang dimiliki sehingga nantinya dapat meningkatkan perekonomian dan bersinergi terhadap masyarakat di Desa Asak. Melalui Laporan Kerja sosial ini diharapkan nantinya dapat memberi informasi bagi penulis dan khususnya bagi Desa Adat Asak mengenai strategi pengembangan pariwisata melalui tradisi budaya. Berdasarkan latar belakang maka penulis mengambil judul "Strategi Pengembangan Pariwisata melalui Tradisi Budaya Terhadap Perekonomian Masyarakat Desa Adat Asak Karangasem”. 


\section{Tujuan}

Memberi informasi mengenai strategi pengembangan pariwisata melalui tradisi budaya terhadap perekonomian masyarakat di Desa Adat Asak Karangasem.

\section{3, Kajian Teori}

\section{Konsep Pariwisata}

Pengertian pariwisata menurut Norval dalam Muljadi dan Nurhayati (2002, h.80) adalah keseluruhan kegiatan yang berhubungan dengan masuk, tinggal, dan pergerakan penduduk asing di dalam atau di luar suatu negara, kota, atau wilayah tertentu. Menurut definisi yang lebih luas yang dikemukakan oleh Kodhyat (1983, h.4) pariwisata adalah perjalanan dari satu tempat ke tempat lain bersifat sementara, dilakukan perorangan atau kelompok, sebagai usaha mencari keseimbangan dan kebahagiaan dengan lingkungan hidup dalam dimensi sosial, budaya, alam, dan ilmu. Selanjutnya menurut Musanef (1995, h.11) mengartikan pariwisata sebagai suatu perjalanan yang dilaksanakan untuk sementara waktu, yang dilakukan dari satu tempat ke tempat yang lain untuk menikmati perjalanan bertamasya dan berekreasi.

\section{Strategi Pengembangan Pariwisata}

Menurut Suryono (2004, h.80) strategi pada prinsipnya berkaitan dengan persoalan: Kebijakan pelaksanaan, penentuan tujuan yang hendak dicapai, dan penentuan cara-cara atau metode penggunaan sarana-prasarana. Strategi selalu berkaitan dengan 3 hal yaitu tujuan, sarana, dan cara. Oleh karena itu, strategi juga harus didukung oleh kemampuan untuk mengantisipasi kesempatan yang ada. Dalam melaksanakan fungsi dan peranannya dalam pengembangan pariwisata daerah, pemerintah daerah harus melakukan berbagai upaya dalam pengembangan sarana dan prasarana pariwisata.

Indonesia sebagai negara yang sedang berkembang dalam tahap pembangunannya, berusaha membangun industri pariwisata sebagai salah satu cara untuk mencapai neraca perdagangan luar negeri yang berimbang. Pengembangan kepariwisataan saat ini tidak hanya untuk menambah devisa negara maupun pendapatan pemerintah daerah. Akan tetapi juga diharapkan dapat memperluas kesempatan berusaha disamping memberikan lapangan 
Jurnal Sewaka Bhakti

Lembaga Penelitian dan Pengabdian Kepada Masyarakat

Universitas Hindu Indonesia Denpasar

Volume 4, Nomor 1 April 2020

ISSN: 2654-2935 (Online)

https://ejournal.unhi.ac.id/index.php/sewakabhakti

pp. 01-20

pekerjaan baru untuk mengurangi pengangguran. Pariwisata dapat menaikkan taraf hidup masyarakat yang tinggal di kawasan tujuan wisata tersebut melalui keuntungan secara ekonomi, dengan cara mengembangkan fasilitas yang mendukung dan menyediakan fasilitas rekreasi, wisatawan dan penduduk setempat saling diuntungkan. Pengembangan daerah wisata hendaknya memperlihatkan tingkatnya budaya, sejarah dan ekonomi dari tujuan wisata. Pariwisata bukan saja sebagai sumber devisa, tetapi juga merupakan faktor dalam menentukan lokasi industri dalam perkembangan daerah-daerah yang miskin sumber-sumber alam sehingga perkembangan pariwisata adalah salah satu cara untuk memajukan ekonomi di daerah-daerah yang kurang berkembang tersebut sebagai akibat kurangnya sumber-sumber alam (Yoeti, 1997).

\section{Tradisi Budaya}

Tradisi merupakan kebiasaan yang dilakukan secara terus-menerus oleh masyarakat dan diwariskan secara turun-temurun (Soekanto Soerjono: 1987 :13) sedangkan budaya adalah suatu cara hidup yang berkembang dan dimiliki bersama oleh sebuah kelompok orang dan diwariskan dari generasi ke generasi. Dapat disimpulkan tradisi budaya merupakan suatu cara hidup yang sudah menjadi kebiasaan sekelompok orang dimana cara tersebut dilakukan terus menerus dan diwariskan dari generasi ke generasi. Adapun fungsi tradisi budaya antara lain:

1. Menjadi representasi suatu daerah atau wilayah tertentu.

2. Sebagai pedoman hubungan manusia dan kelompok.

3. Memenuhi kebutuhan masyarakat sekitar.

4. Sebagai media berkomunikasi dengan individu atau kelompok lainnya.

5. Mendorong terjadinya perubahan masyarakat.

6. Menjadi identitas bangsa secara nasional.

\section{Wisata Budaya}

Pendit, (1990) menyebutkan wisata budaya adalah perjalanan yang dilakukan atas dasar keinginan untuk memperluas pandangan hidup seseorang dengan jalan mengadakan kunjungan ke tempat lain atau ke luar negeri, mempelajari keadaan rakyat, kebiasaan dan 
adat istiadat mereka, cara hidup mereka, kebudayaan dan seni mereka. Dewasa ini, pariwisata budaya berkembang dengan cepat karena adanya tren baru di kalangan wisatawan yaitu kecenderungan untuk mencari sesuatu yang unik dan autentik dari suatu kebudayaan. Bentuk kegiatan wisata budaya salah satunya adalah dengan mengunjungi desa wisata. Pemahaman istilah desa wisata cukup beragam. Nuryanti, Wiendu (1993) menyebutkan bahwa Desa wisata didefinisikan sebagai bentuk integrasi antara atraksi, akomodasi, dan fasilitas pendukung yang disajikan dalam suatu struktur kehidupan masyarakat yang menyatu dengan tata cara tradisi yang berlaku. Penetepannya harus memenuhi persyaratan di antaranya:

1. Aksesibilitasnya baik, sehingga mudah dikunjungi wisatawan dengan menggunakan berbagai jenis alat transportasi.

2. Memiliki obyek-obyek menarik berupa alam, seni budaya, legenda, makanan lokal, dan sebagainya untuk dikembangkan sebagai obyek wisata.

3. Masyarakat dan aparat desanya menerima dan memberikan dukungan yang tinggi terhadap desa wisata serta para wisatawan yang datang ke desanya.

4. Keamanan di desa tersebut terjamin.

5. Tersedia akomodasi, telekomunikasi, dan tenaga kerja yang memadai.

6. Beriklim sejuk atau dingin.

\section{Metode Pengabdian}

\section{Obyek Pengabdian}

Desa Adat Asak merupakan desa yang terletak di Kedesaan Pertima, kecamatan Karangasem, Kabupaten Karangasem, Desa Adat Asak berada di hulu kedesaan Pertma. Secara tofografi, Desa Adat Asak, Kecamatan Karangasem Kabupaten Karangasem merupakan daerah daratan tinggi dengan ketinggian 200 s/d 450 meter diatas permukaan laut, curah hujan relatif tinggi, dengan batas wilayah administrative sebagai berikut :

- Sebelah Utara berbatasan dengan Bungaya

- Sebelah Timur berbatasan dengan Subagan

Desa Adat Asak diperkirakan ada pada tahun 1630 (Sumber Prasasti Asak dan Silsilah Bendesa Rani Satru, Desa Adat Asak terdiri dari 2 Banjar Adat yaitu, Banjar Adat 
Asak Kangin dan Banjar Adat Asak Kauh. Desa Adat Asak tergolong salah satu desa kuna yang ada di Kabupaten Karangasem, tepatnya di Desa Dinas Pertima, Kecamatan Karangasem, lokasinya sekitar $4 \mathrm{~km}$ dari kota Amlapura ke arah barat menuju jalan ke Denpasar. Sebagai sebuah sosok desa kuna tentu syarat akan aktivitas ritual agama dan tradisi budayanya yang unik. Aktivitas ritual agama dan budaya yang hingga kini masih ajeg di Desa Adat Asak sangatlah banyak beberapa diantaranya : Usaba Kaulu, Usaba Muhu-Muhu, Usaba Sumbu, Rejang, Pendet dan Gebug/Maniang. Salah satu ritual keagamaan Desa Adat Asak yang cukup unik adalah Usaba Kaulu (Ngusaba Ngaulu), Nyepeg Sampi (pembunuhan/tebas sapi) namanya, salah satu rangkaian kegiatan Usaba Kaulu yang tergolong dalam dalam upacara Bhuta Yadnya (pecaruan) untuk menetralisir alam wilayah desa dari gangguan mahkluk jahat. Ritual tersebut rutin digelar setiap sasih kaulu.

\section{Metode Pengumpulan Data}

1. Observasi

Observasi merupakan pengumpulan data dengan cara mengamati, meneliti atau mengukur kejadian yang sedang berlangsung. Dengan cara ini data yang diperoleh merupakan data yang factual dan actual dalam artian data yang dikumpulkan diperoleh saat peristiwa berlangsung (Endar Sugiarto dan Kusmayadi, 2000).

Observasi dilakukan secara langsung dengan mengamati tentang kondisi Desa Adat Asak Karangasem meliputi, Prasasti, Peninggalan sejarah, Pura-Pura, aksesbilitas, fasilitas umum, potensi, obyek wisata dan pengelolaan yang sudah dilakukan saat itu.

2. Wawancara

Wawancara merupakan proses interaksi dan komunikasi antara pengumpul redaksi dan dengan koresponden. Sehingga wawancara dapat diartikan sebagai cara mengumpulkan data dengan bertanya langsung kepada koresponden, dan jawabanjawaban di catat atau direkam dengan alat perekam (Endar Sugiarto dan Kusmayadi,2000,83).

Pengumpulan data dengan melakukan wawancara dan Tanya jawab kepada aparat desa dan tokoh agama sekitar Desa Adat Asak sehingga mendapatkan data-data yang 
jelas, terperinci yang berkaitan dengan sejarah Desa maupun hal-hal lainnya yang menyangkut obyek penelitian tersebut.

3. Studi Pustaka

Studi pustaka yaitu teknik pengumpulan data yang dilakukan dengan cara mengumpulkan bahan-bahan yang relevan meliputi literature, referensi maupun bukubuku yang mendukung penelitian. Tahap ini digunakan guna memperoleh data-data yang akurat sebagai pendukung data yang diperoleh dari pengamatan dan wawancara.

Studi Pustaka yang digunakan pada penelitian ini adalah dengan cara membaca buku dan tulisan yang berkaitan dengan Desa Adat Asak Karangasem.

\section{Metode Analisis Data}

Metode analisis data yang diguanakan dalam penelitian ini yaitu Metode Analisis SWOT. Data yang diperoleh kemudian dikaji dengan cara menganalisis faktor lingkungan internal (kekuatan,kelemahan) dan faktor lingkungan eksternal (peluang dan ancaman) yang ada atau dengan menggunakan anaisis SWOT,selain daripada itu juga analisis tersebut digunakan untuk mengetahui peluang yang ada di Desa Adat Asak Karangasem. Analisa ini didasarkan pada logika yang dapat memaksimalkan kekuatan (strength) dan peluang (oppurtunities) namun secara bersamaan meminimalkan kelemahan (weaknesses) dan ancaman (threats).

\section{Hasil Dan Pembahasan}

\section{Potensi-Potensi Wisata Melalui Tradisi Budaya Desa Adat Asak Karangasem}

1. Usaba Muhu-Muhu

Sebuah momen yang diselenggarakan selama setahun sekali di Desa Adat Asak Karangasem. Tradisi Usaba Muhu-muhu di Desa tua ini sesungguhnya adalah ritual mecaru desa. Hal itu sebagai media memupuk kebersamaan dan mengeratkan tali persaudaraan seluruh karma desa melalui pelaksanaan makan bersama yang disebut megibung yang merupakan ikon budaya disana. Pihak desa pekraman setempat menyiapkan lebih dari seratus gibungan untuk seluruh krama desa mulai 
anak-anak, remaja, sampai orang tua. Seluruh krama desa berpartisipasi dalam persiapannya mulai dari mengolah berbagai macam bumbu-bumbuan alias mebat, ngikih, ngarang, murak daging sapi dan memanggangnya. Sedangkan untuk kelengkapan upacara caru dan upacara lainnya dipersiapkan oleh kelompok undagi. Upacara tersebut dilakukan selama sehari di Pura Dalem Tengah. Warga megibung di tempat terpisah-pisah dengan memanfaatkan ke empat Bale Pauman, Bale Seka Gong, Bale Lantang, hingga Bale Sanggar. Tradisi ini berlangsung turun-temurun sebagai cara memupuk rasa kebersamaan. Gibungan ini diolah dari sisa sapi yang dipakai untuk sarana caru. Setiap satu gibungan ditempati enam hingga delapan orang. Jika ada warga yang tidak boleh memakan daging sapi maka telah disiapkan enam gibungan dengan menggunakan daging ayam.

Ritual Usaba Muhu-muhu ini dilaksanakan dalam bentuk caru desa dengan tujuan untuk nyomia bhuta kala menjadi bhuta hita. Sehingga nantinya krama desa senantiasa hidup harmonis diantara alam semesta. Pelaksanaan upacara ini diawali ritual nyaga. Tiga hari sebelum upacara ini warga melaksanakan ritual ini untuk nyomia bhuta kala dalam tingkatan kecil agar tidak mengganggu pekarangan warga. Ritual ini juga disebut ritual metuun buah. Pada saat Usaba muhu-muhu, ritual nyomia dilakukan dalam tingkatan tinggi oleh desa adat. Sarananya caru seekor kerbau dan juga sapi. Dari beberapa sumber sastra yang ada di Desa ini, tradisi aci usaba тиһи-тиhи ini juga dipandang sebagai penerapan Kitab Shiva Purana.Ketika berwujud sapi dan kerbau. Pada zaman ini diperingati sebagai bentuk pengendalian diri agar manusia terhindar dari sifat-sifat hewani. 
2. Usaba Kaulu

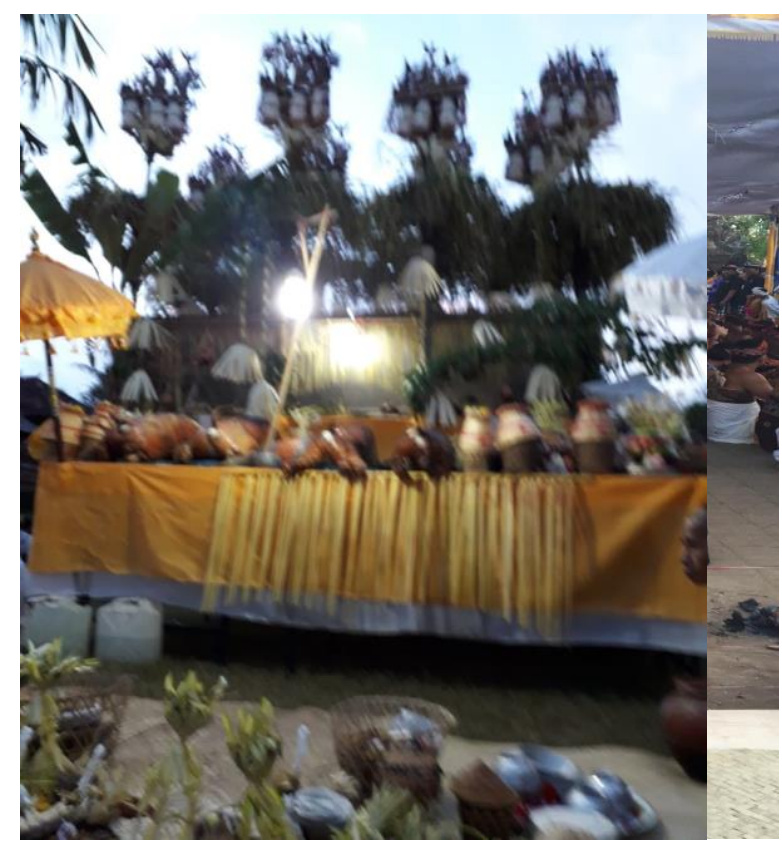

Upacara ini merupakan upacara yang berlangsung setahun sekali bertepatan dibulan Januari atau Februari. Nyepeg sampi/tebas sapi namanya, salah satu rangkaian kegiatan usaba Kaulu yang tergolong dalam upacara Bhuta Yadnya (pecaruan) untuk menetralisir alam wilayah desa dari gangguan makhluk jahat. Pelaksanaan ritual nyepeg sampi didominasi oleh para seke dehe-teruna Asak. Para terunanya mengenakan busana kain warna hitam dibalut saput warna putih diikat sabuk poleng (warna hitam putih) dengan mengenakan destar warna merah tapi tanpa mengenakan baju serta senjata yang digunakan untuk "nyepeg sampi" adalah jenis belakas sudamala yang khusus digunakan untuk ritual usaba Kaulu. Pisau itu menggunakan bahan baku baja dan pegangan senjata itu terbuat dari perak. Sedangkan para teruninya mengenakan kebaya seragam brokat warna kuning dan kainnya warna warni membawa bokor dilengkapi sesajen kembang.

Dimulai Jero Mangku mempersiapkan penataan banten di Pura Patokan, sementara para terunanya menyucikan sapi dengan sarana upacara dan menghiasnya dengan kain warna-warni di jaba Pura Puseh Sapi yang digunkan bukan sapi sembarangan, harus dicari sapi yang besar dan tanpa cacat dan juga harus berjenis 
kelamin jantan lengkap dengan buah pelirnya.Selain itu dipelihara satu minggu oleh pemuda dan sebelum dijadikan caru dibuatkan dulu banten dan upacara khusus. Disampaikan bahwa sapi yang dilepas lalu dibunuh itu adalah sapi yang sudah diberkati Ida Betare sehingga tetesan darahnya itu selain sebagai caru juga untuk kesuburan dan kemakmuran.

Seekor sapi diarak keliling desa diiringi gamelan Baleganjur dan diikuti oleh seluruh dehe-teruna dan krama Desa Adat Asak. Di Pura Patokan sapi diupacarai dengan mengelilingi Palinggih Patokan sebanyak tiga kali. Setelah upacara di Pura Patokan, penyepegan sampi segera dimulai. Begitu sapi dilepas dari talinya keluar dari pintu balai banjar langsung lari menuju arah selatan, melihat sapi telah keluar dari balai banjar, saat itu pula langsung dikejar sambil bersorak-sorai kegirangan oleh ratusan teruna sembari membawa blakas untuk disepeg serta diikuti oleh krama desa lainnya. Arah sapi berlari, memiliki makna sendiri. Kalau sapi berlari ke arah utara, mengandung arti kesuburan. Timur melambangkan adanya cahaya kebahagiaan. Selatan itu kemakmuran dan kebijaksanaan. Barat berarti adanya kegelapan di alam.

Sembari berlari mengejar sapi, beberapa meternya tubuh sapi sudah dapat disepeg beramai-ramai oleh teruna, darah merah segar sapi pun muncrat, bahkan muncrat darahnya mengenai tubuh teruna. Baru berlari sekitar 100 meter ke arah selatan sapi gemuk akhirnya tumbang menghembuskan napas terakhir dan tergeletak di jalan raya.Kemudian sapi tersebut dicabik-cabik organ tubuhnya. Pertama kepala sapi dipotong langsung dibawa ke banjar. Organ tubuh sapi lainnya menyusul dibawa ke balai banjar untuk dibuatkan bayang-bayang berbentuk seekor sapi untuk diolah dijadikan bahan caru, dan sisanya diolah untuk dimakan megibung (makan bersama) bersama: teruna-deha, pecalang dan krama saing (karma desa). 
3. Usaba Sumbu.

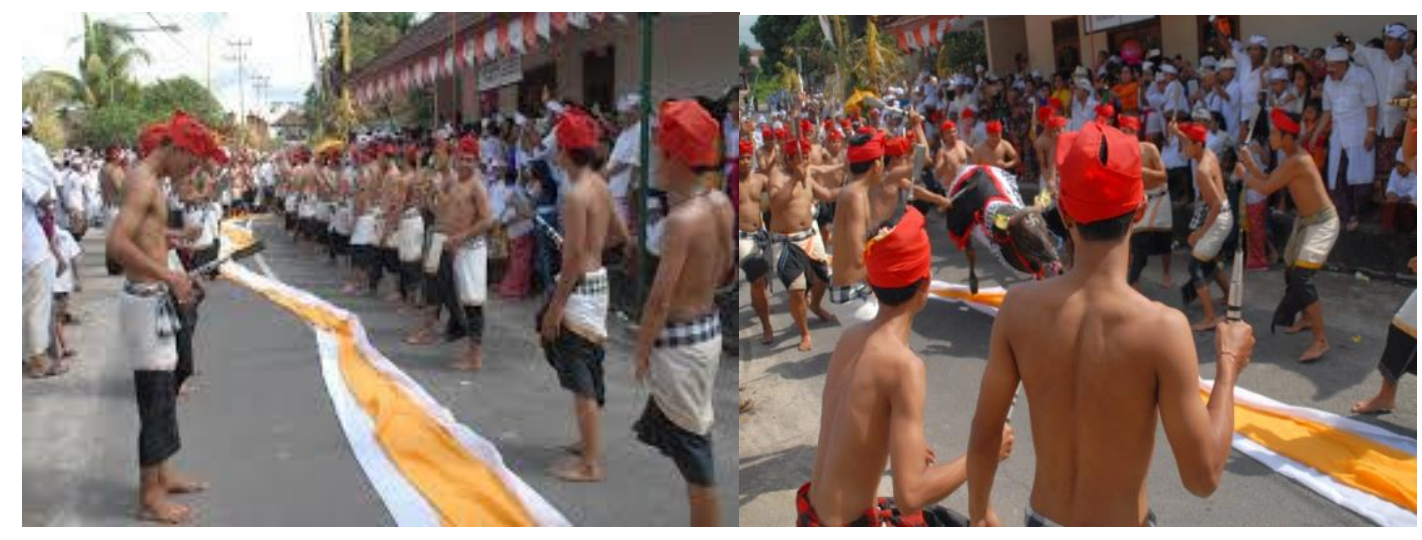

Sumbu merupakan sebuah poros (pusat). Poros atau sumber kehidupan untuk mencapai sunia (kedekatan dengan Tuhan). Dari beberapa literatur penelitian berbagai kalangan menyebutkan, Usaba Sumbu di gelar sebagai penyambutan Ida Sang Hyang Widhi Wasa dengan sarana upacara tiang lurus yang dihiasi berbagai perlengkapan yang kemudian disebut Sumbu. Bentuknya bersusun mengerucut. Pada bagian paling atas terdapat manuk dewata yang dipercaya membawa amanah dari persembahan warga. Persembahan tulus ikhlas, wujud bhakti warga yang ditujukan kepada tuhan yang Maha Esa. Harga satu sumbu bisa menghabiskan biaya Rp. 15 juta karena satu sumbu di bangun dengan banyak rangkaian seperti rerenteng, bungan langkuas, reringgitan naga sari, wayang, yang rangkaiannya sangat rumit.

Dalam proses nyujukan (mendirikan-red) sumbu, sebelumnya dilakukan ritual nyulubin sumbu. Saat itu, sumbu didirikan di tempat bebas, gadis yang mendapat ayahan sumbu dengan menggunakan pakaian adat rejang sederhana, masuk pada pangkal sumbu. Sumbu lalu di putar - putar oleh truna adat. Ritual itu diibaratkan sebagai peristiwa pemutaran gunung Mandara Giri dengan Sumbu dilambangkan sebagai Buana Agung. Pemutaran dilakukan oleh truna adat, karena di percaya truna adat dalam usia yang masih remaja masih melekat sifat - sifat keraksaaan. Sesuai dengan cerita itu, bahwa pemutaran Gunung Mandara Giri dilakukan oleh raksasa. Dalam cerita pemutaran gunung Mandara Giri, diceritakan saat lautan diaduk, racun mematikan yang disebut Halahala menyebar. Racun tersebut diceritakan dapat membunuh segala makhluk hidup. Dewa Siwa kemudian 
meminum racun tersebut, maka lehernya menjadi biru. Setelah itu, berbagai dewadewi, binatang, dan harta karun bermunculan, diantaranya, Sura, Dewi yang menciptakan minuman anggur, Apsara, kaum bidadari kahyangan, Kostuba, permata yang paling berharga di dunia, Uccaihsrawa, kuda para Dewa, Kalpawreksa, pohon yang dapat mengabulkan keinginan, Kamadhenu, sapi pertama dan ibu dari segala sapi, Airawata, kendaraan Dewa Indra, dan Laksmi, Dewi keberuntungan dan kemakmuran. Kemudian munculah Dhanwantari membawa kendi berisi tirta amerta yang diceritakan bisa membuat hidup abadi para dewa.

Dari beberapa penglingsir desa yang di temui, mereka sepakat mengatakan bahwa anak gadis yang mendapat ayahan sumbu, melambangkan seorang dewi laksmi, yang dalam cerita itu adalah dewi pembawa keberuntungan dan kemakmuran. Keberuntungan dan kemakmuran bagi keluarga dan secara umum kepada desa adat. Di pilihnya seorang gadis dalam ayahan sumbu, karena seorang gadis nantinya akan menjadi ibu. Ibu nantinya memiliki peran besar dalam menjalankan roda kehidupan.

Setiap pelaksanaan usaba sumbu, desa adat melalui empat Pauman, yakni Pauman Beji, Pauman Desa, Pauman Manak Yeh, dan Pauman Lambuan, menunjuk masing - masing seorang gadis untuk mewakili masing - masing Pauman. Kecuali Pauman Desa diwakili oleh dua orang gadis, karena Pauman ini warganya paling banyak, dan menurut cerita leluhur merupakan warga wed (asli) desa adat Timbrah. Dari lima gadis itu, tiga diantaranya ngayah pada usaba kaja, dan sisanya ngayah pada usaba kelod.

Rangkaian Usaba Sumbu dilaksanakan dalam satu minggu. Diawali dengan upacara melasti ke segara. Tiga hari kemudian desa adat setempat menggelar puncak Usaba Sumbu Kaja. Persembahyangan dilangsungkan tengah malam sekitar pukul 24.00 Wita. Keesokan harinya disebut pengajengan. Pada hari itu dilaksanakan tabuh rah yang bertujuan menyomyakan bhuta kala. Setelah pengajengan disebut penyelagan. Hari ini di pakai untuk mempersiapkan segala perlengkapan, seperti perlengkapan upacara untuk di pakai pada Usaba Kelod. Setelah itu, hari berikutnya, barulah Usaba Sumbu Kelod. Usaba Sumbu Kelod 
Jurnal Sewaka Bhakti

Lembaga Penelitian dan Pengabdian Kepada Masyarakat

Universitas Hindu Indonesia Denpasar

Volume 4, Nomor 1 April 2020

ISSN: 2654-2935 (Online)

https://ejournal.unhi.ac.id/index.php/sewakabhakti

pp. 01-20

ditujukan kepada Ida Betara Sri Rambut Sedana dengan mendirikan dua buah Sumbu, dan babi guling.

Pada malam harinya dilaksanakan upacara ngundangin. Upacara ini tergolong sakral, dengan pengucapan mantra - mantra oleh kelian Daa dalam keadaankerauhan, yang di ikuti sorak sorai truna adat agar mantra yang diucapkan tidak di dengar pihak lain. Bahkan warga yang melakukan dokumentasi, dilarang pecalang setempat. Setelah itu, hari berikutnya desa adat melakukan upacara penyineban sebagai akhir dari rangkaian aci Usaba Sumbu.

4. Tari Rejang Dehe

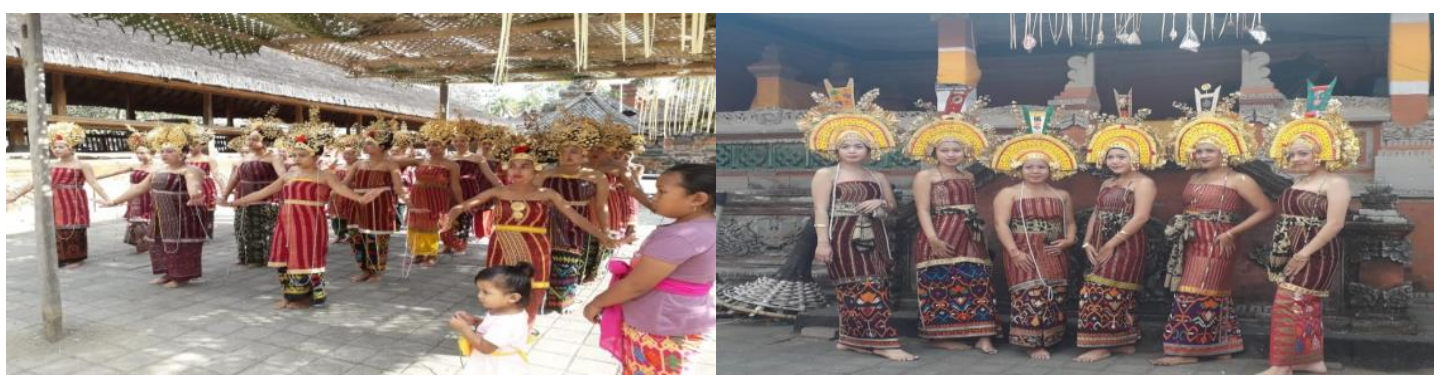

Tari Rejang Dehe merupakan tarian yang sudah ada pada abad XVI yang diwarisi oleh sesepuh seni Desa Asak Karangasem. Munculnya tari ini bertujuan untuk memohon keselamatan dan ketentraman ring Ida betara Bale Agung. Ketentraman dan kedamaian adalah merupakan idalam dalam kehidupan masyarakat Desa Adat Asak Karangasem. Wujud nyata rasa syukur atas anugrah yang diberikan oleh Hyang Widhi Wasa dituangkan dalam bentuk tari rejang Dehe. Tari ini dipentaskan saat Usaba Kasa, Hari Raya Kuningan, hari raya Keenem.Tari Rejang Dehe merupakan tarian yang hanya boleh dipentaskan oleh perempuan yang sudah akhil balik serta belum menikah.Selain itu, yang paling penting hanya gadis desa itu yang diizinkan untuk menari rejang. Meskipun masyarakat Desa Asak bukanlah satu-satunya yang melaksanakan ritual tari rejang. Masyarakat Desa Asak berpartisipasi dalam Rejang Dehe, setiap keluarga hanya boleh mengirimkan satu orang anak gadis sebagai perwakilan. Oleh karena menjadi penari Rejang menjadi sebuah tugas yang membanggakan keluarga dan menyangkut kehormatan keluarga. 


\section{Strategi-Strategi Pengembangan Pariwisata di Desa Adat Asak Karangasem}

1. Memperhatikan Lingkungan Desa Wisata

Langkah yang dilakukan yaitu meningkatkan kebersihan dan penataan pariwisata yang baik di Desa Adat Asak Karangasem. Dimana upaya yang sudah ada dan perlu dioptimalkan lagi yaitu upaya Desa dalam pembersihan Desa dari sampah dan mengadakan pengolahan sampah organic dengan menggunakan alat pencacah sampah. Selain itu, upaya yang dilakukan oleh Desa yaitu memberi edukasi masyarakat tentang pentingnya sadar wisata.

2. Pengembangan dan pengelolaan Sarana dan Prasarana

Untuk mewujudkan desa wisata yang berkembang tentu perlu memperhatikan sarana dan prasarananya karena hal yang penting dalam memajukan pariwisata maka dibutuhkan sarana dan prasarana lengkap seperti, ketersediaan fasilitas umum , transportasi umum, penginapan dan lain sebagainya.

3. Peran serta Masyarakat

Sesuai dengan hasil wawancara yang sudah dilakukan dengan bapak Kepala Dusun Desa Adat Asak ,beliau mengatakan bahwa peran masyarakat Desa ini sangat minim karena sebagian besar penduduk desa ini merantau ke kota, sehingga perlu adanya kesadaran masyarakt untuk memajukan desanya. Selain itu,setelah kami perdalam dengan pedagang yang ada disekitar obyek yang merupakan lokasi diselenggarakannya tradisi budaya tersebut bahwa mereka belum banyak terlibat dan mendapatkan keuntungan dari adanya wisatawan yang masuk. Hanya saja beberapa kios dagang yang sempat menjadi perhatian wisatawan karena menjual soft drink dan cemilan. Sehingga mereka mendapatkan kontribusi dari wisatawan yang datang.

4. Pembinaan secara Berkesinambungan

Melakukan pembinaan berkesinambungan terhadap pelaku budaya yang ada agar potensi budaya menjadi daya tarik tidak hilang dimakan perkembangan zaman yang semakin modern, walaupun sebenarnya untuk saat ini wisatawan banyak tertarik untuk mengunjungi obyek wisata yang memiliki daya tarik budaya dan alam yang terdapat di pedesaaan daripada mengunjungi obyek wisata perkotaan. Tingginya 
wisatawan yang berkarakter Nature based, pada satu sisi sangat positif dan bermanfaat, akan tetapi pada sisi lain terlihat belum adanya pendalaman terhadap fungsi lingkungan atau masih banyak masyarakat yang belum sadar akan pentingnya "Nature Related Tourism"

\section{Dampak Pengembangan Pariwisata Melalui Tradisi Budaya Terhadap Perekonomian di Desa Adat Asak Karangasem}

\section{Dampak Pada Aspek Sosial}

Hasil wawancara yang dilakukan oleh beberapa warga setempat bahwa untuk saat ini warga sebagian besar masih bermata pencaharian sebagai petani dan sisanya bermata pencaharian pedagang dan merantau ke luar kota. Belum adanya pengaruh yang signifikan terhadap perilaku yang ditimbulkan oleh wisatawan. Dengan adanya pengembangan pariwisata di Desa Asak Karangasem tentu diharapkan memiliki dampak positif nantinya bagi masyarakat dimana masyarakat desa tidak lagi merantau keluar kota melainkan membuka usaha sendiri di desanya dengan memanfaatkan potensi-potensi yang ada dan diharapkan adanya lapangan kerja yang timbul pengembangan pariwisata Desa Adat Asak Karangasem.

\section{Dampak Pada Aspek Ekonomi}

Hasil wawancara yang dilakukan oleh salah satu kios dagang yang ada di seputaran obyek dilangsungkannya tradisi budaya bahwa hingga saat ini belum adanya kontribusi sepenuhnya dari wisatawan yang datang karena pada umumnya wisatawan yang datang hanya berkunjung beberapa jam dan setelah itu pergi dan tidak ada yang tinggal atau menginap diseputaran desa. Dalam pengembangan pariwisata di Desa Adat Asak Karangasem ini nantinya tentu diharapkan dapat memberi pengaruh pada aspek ekonomi dengan wisatawan yang datang diharapkan barang dagangan masyarakat desa setempat dapat laku terjual sehingga meningkatkan pendapatan ekonomi masyarakat. Dengan meningkatnya pendapatan masyarakat diharapkan dapat membantu mensejahterakan masyarakat setempat. 
Jurnal Sewaka Bhakti

Lembaga Penelitian dan Pengabdian Kepada Masyarakat

Universitas Hindu Indonesia Denpasar

Volume 4, Nomor 1 April 2020

ISSN: 2654-2935 (Online)

https://ejournal.unhi.ac.id/index.php/sewakabhakti

pp. $01-20$

Aspek-Aspek yang perlu Diperhatikan Dalam Pengembangan Pariwisata Desa Adat Asak Karangasem

1. Aspek Perencana, dimana mencakup sistem perencanaan kawasan, penataan ruang, standarisasi, identifikasi potensi, dan pendanaan.

2. Aspek sarana dan prasarana, dimana daya dukung dan pemanfaatan secara optimal.

3. Aspek pengelolaan, dimana mengembangkan profesionalisme dan pola pengelolaan yang siap mendukung kegiatan pariwisata sehingga mampu memanfaatkan potensi yang ada.

4. Aspek pengusahaan, dimana memberi kesempatan dan mengatur pemanfaatan untuk tujuan pariwisata yang bersifat komersial kepada pihak ketiga dan membuka lapangan kerja bagi masyarakat setempat.

5. Aspek pemasaran, dimana usaha dalam menggunakan teknologi tinggi dan bekerja bersama beberapa pihak baik dalam dan luar negeri seperti media sosial, media masa, brosur dan lain-lainnya.

6. Aspek Peran Masyarakat, dimana melalui kesempatan-kesempatan usaha sehingga mampu mensejahterakan masyarakat setempat (seperti, ojek,homestay dan lainlainnya).

7. Aspek Penelitian ,dimana sebagai informasi bagi pengembangan kawasan, kebijaksanaan dan arahan pemanfaatan.

\section{Analisis SWOT}

Analisis SWOT dilakukan pada faktor lingkungan internal dan faktor lingkungan eksternal, yang secara langsung dapat mempengaruhi perkembangan di Desa Adat Asak Karangasem. Faktor-faktor tersebut adalah sebagai berikut :

1. Faktor Internal

a. Kekuatan (strength)

- Memiliki tradisi budaya unik yang merupakan tradisi turun-temurun seperti Usaba Kaulu, Usaba Muhu-muhu, Usaba Sumbu, Tari Rejang dan Pendet yang keunikannnya sudah dikenal hingga luar negeri. 
- Kaya akan kearifan lokal.

- Desa ini memiliki pemandangan alam yang asri yang dapat menjadi wisata alternatif.

- Aksesbilitas mudah.

b. Kelemahan (Weakness)

- Belum adanya fasilitas umum yang dapat digunakan para wisatawan yang datang seperti lahan parkir, toilet umum dan belum adanya fasilitas penginapan baik hotel atau villa.

- Potensi pemandangan alam belum dimanfaatkan secara optimal.

- Kualitas sdm belum memadai.

- Pola kemitraan belum dilaksanakan secara baik.

- Promosi keberadaan Wisata Budaya Desa Adat Asak Karangasem masih belum efektif.

2. Faktor Eksternal

a. Peluang (Opportunity)

- Minat investor untuk memiliki usaha di Desa Adat Asak Karangasem.

- Pasar pariwisata domestik dan internasional yang tinggi.

- Dukungan masyarakat dunia (dengan adanya hasil penelitian)

b. Ancaman ( Threat)

- Masuknya perubahan-perubahan budaya yang dipengaruhi oleh perkembangan globalisasi.

- Stabilitas nilai tukar Rupiah yang labil.

- Ancaman bencana alam.

- Kebijakan politik luar negeri dan dalam negeri yang dapat mengakibatkan turunnya jumlah kunjungan. 


\section{Penutup}

\section{Simpulan}

Berdasarkan hasil dan pembahasan pengabdian diatas dapat ditarik kesimpulan bahwa:

1. Adapun beberapa potensi-potensi yang dimiliki oleh Desa Adat Asak Karangasem yang dapat dikembangkan menjadi wisata budaya yaitu Tradisi Usaba Muhu-muhu, Usaba Sumbu dan Usaba Kaulu serta Tari Rejang Dehe Desa Adat Asak Karangasem.

2. Strategi-Strategi Pengembangan Pariwisata di Desa Adat Asak Karangasem antara lain :

a. Memperhatikan Lingkungan Desa Wisata

Langkah yang dilakukan yaitu meningkatkan kebersihan dan penataan pariwisata yang baik di Desa Adat Asak Karangasem. Dimana upaya yang sudah ada dan perlu dioptimalkan lagi yaitu upaya Desa dalam pembersihan Desa dari sampah dan mengadakan pengolahan sampah organic dengan menggunakan alat pencacah sampah. Selain itu, upaya yang dilakukan oleh Desa yaitu memberi edukasi masyarakat tentang pentingnya sadar wisata.

b. Pengembangan dan pengelolaan Sarana dan Prasarana

Untuk mewujudkan desa wisata yang berkembang tentu perlu memperhatikan sarana dan prasarananya karena hal yang penting dalam memajukan pariwisata maka dibutuhkan sarana dan prasarana lengkap seperti, ketersediaan fasilitas umum , transportasi umum, penginapan dan lain sebagainya.

c. Peran serta Masyarakat

Sesuai dengan hasil wawancara yang sudah dilakukan dengan bapak Kepala Dusun Desa Adat Asak ,beliau mengatakan bahwa peran masyarakat Desa ini sangat minim karena sebagian besar penduduk desa ini merantau ke kota, sehingga perlu adanya kesadaran masyarakt untuk memajukan desanya. Selain itu,setelah kami perdalam dengan pedagang yang ada disekitar obyek yang merupakan lokasi diselenggarakannya tradisi budaya tersebut bahwa mereka belum banyak terlibat dan mendapatkan keuntungan dari adanya wisatawan yang masuk. Hanya saja beberapa 
kios dagang yang sempat menjadi perhatian wisatawan karena menjual soft drink dan cemilan. Sehingga mereka mendapatkan kontribusi dari wisatawan yang datang.

d. Pembinaan secara Berkesinambungan

Melakukan pembinaan berkesinambungan terhadap pelaku budaya yang ada agar potensi budaya menjadi daya tarik tidak hilang dimakan perkembangan zaman yang semakin modern, walaupun sebenarnya untuk saat ini wisatawan banyak tertarik untuk mengunjungi obyek wisata yang memiliki daya tarik budaya dan alam yang terdapat di pedesaaan daripada mengunjungi obyek wisata perkotaan. Tingginya wisatawan yang berkarakter Nature based, pada satu sisi sangat positif dan bermanfaat ,akan tetapi pada sisi lain terlihat belum adanya pendalaman terhadap fungsi lingkungan atau masih banyak masyarakat yang belum sadar akan pentingnya "Nature Related Tourism"

3. Dampak Pada perekonomian masyarakat Desa Adat Asak Karangasem melalui pengembangan pariwisata.

Dengan menerapkan beberapa strategi-strategi pengembangan pariwisata diharapkan mampu meberikan pengaruh besar nantinya bagi perekonomian masyarakat setempat melalui kontribusi wisatawan yang datang dengan menciptakan lapangan kerja sebanyak-banyaknya dan berpengaruh besar bagi pedagang-pedagang yang ada sehingga dagangan yang ditawarkan dapat laku terjual dengan adanya wisatawan yang datang.

\section{Saran}

Adapun beberapa saran dari penulis untuk penelitian ini antara lain:

1. Strategi Pengembangan Pariwisata di Desa Adat Asak Karangasem dapat dimaksimalkan dengan memberikan edukasi pada masyarakat setempat tentang pentingnya sadar wisata, memberikan informasi beberapa strategi pengembangan pariwisata dan dampak yang akan didapat jika nantinya dapat di implementasikan secara merata dan optimal. 
2. Memperhatikan dan memfokuskan kepada beberapa aspek pengembangan pariwisata sehingga masyarakat Desa Adat Asak Karangasem memiliki tujuan yang jelas kemana arah dan tujuan yang akan dicapai dalam memajukan wisata khususnya melalui tradisi budaya yang dimiliki.

3. Bekerjasama dengan pemerintah dalam upaya pengembangan pariwisata harapannya pemerintah membantu memfasilitasi apa yang dibutuhkan nantinya, dalam penataan dan kebijakan yang baik untuk diterapkan.

4. Harus dilakukan studi banding ke daerah-daerah yang maju dengan pariwisata budaya sehingga hasil studi banding tersebut dapat dijadikan bahan dalam menyusun strategi pengembangan pariwisata Desa Adat Asak Karangasem selanjutnya.

\section{UCAPAN TERIMA KASIH}

Terima kasih untuk Universitas Mahendradatta yang sudah memberikan kesempatan dalam melakukan Pengabdian kepada Masyarakat yang telah dilakukan di Desa Adat Asak, kecamatan Karangasem, kabupaten karangasem. Kegiatan Pengabdian ini sangat berguna baik bagi akademisi dan juga Masyarakat sekitar.

\section{DAFTAR PUSTAKA}

Administrasibisnis.studentjournal.ub.ac.id

https://pertimakarangasem.wordpress.com/desa-asak/

http://cvinspireconsulting.com/konsep-pengembangan-pariwisata/

Jurnal Administrasi Bisnis (JAB) Vol.32 No.1 Maret 2016

Jurnal kajian hukum Vol. 1 no 2 (2016) 